\title{
An Elegant and Learned Discourse of the Light of Nature
}

Composed in a period of religious and political upheaval, Culverwell's Discourse of the Light of Nature is an imaginative statement of the teachings of Christian humanism concerning the nature and limits of human reason and the related concepts of natural and divine law. The lengthy introduction to this new critical edition throws light on the evolution of English rationalism in the seventeenth century, and the annotation establishes for the first time the full range of Culverwell's sources - classical, medieval, and Renaissance - and enables the reader to appreciate his manner of citing authority and handling illustration.

(Department of English Studies and Texts 17)

ROBERT A. GREENE received an MA from Boston College and a PH D from Harvard University. He has been a member of the faculty of the University of Toronto since 1958, and is now Professor of English at University College.

HUGH R. MACCALLUM received a PH D from the University of Toronto, and joined the faculty of the university in 1959. He is now Professor of English at University College. He is working on A Preface to Milton, to be published by University of Toronto Press. 


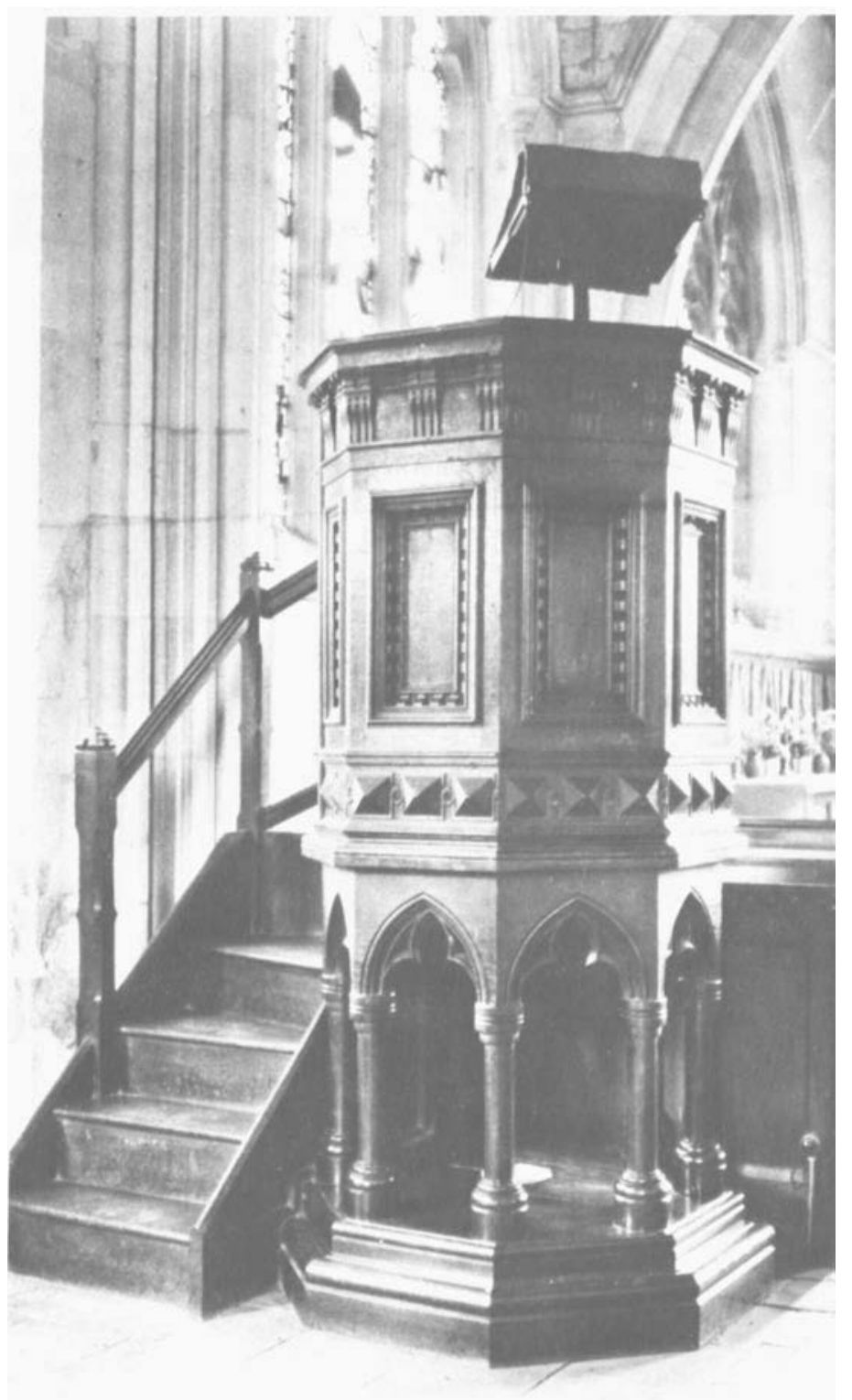




\title{
An Elegant and Learned Discourse of the Light of Nature
}

\author{
NATHANIEL CULVERWELL
}

\author{
จิจัจุ \\ EDITED BY \\ Robert A. Greene AND Hugh MacCallum
}




\section{UNIVERSITY OF TORONTO \\ DEPARTMENT OF ENGLISH STUDIES AND TEXTS}

I7

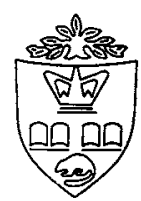

(c) University of Toronto Press I971

All rights reserved

Manufactured in the United States of America for

University of Toronto Press, Toronto and Buffalo

$$
\begin{gathered}
\text { ISBN } 0-8020-523 I-2 \\
\text { LC } 74-151369
\end{gathered}
$$

The restored pulpit from which Culverwell delivered the Discourse, sold by Emmanuel College when the chapel was converted into a library and presented in 1677 to the church of Sts. Mary and Nicholas, Trumpington, where it remains.

Frontispiece courtesy of Royal Commission on Historical Monuments (England). Crown Copyright. 